\title{
INTEGRATION OF CONTEMPORARY ARCHITECTURE WITH NATURAL AND CULTURAL ENVIRONMENT (WATER RESERVOIRS IN HARBOUR COMPLEXES: HAFEN CITY HAMBURG AND ŁASZTOWNIA IN SZCZECIN)
}

\author{
INTEGRACJA WSPÓŁCZESNEJ ARCHITEKTURY ZE ŚRODOWISKIEM \\ PRZYRODNICZYM I KULTUROWYM (AKWENY W ZESPOŁACH \\ PORTOWYCH: HAFEN CITY W HAMBURGU I ŁASZTOWNIA W SZCZECINIE)
}

Piotr Fiuk

dr hab. inż. arch., prof. ZUT

Author's Orcid number: 0000-0001-8751-4378

West Pomeranian University of Technology in Szczecin

Faculty of Architecture

Department of History and Theory of Architecture

\begin{abstract}
The unique location in post-industrial areas neighbouring with the centres of modern cities, bordering with natural landscape areas and having the access to water reservoirs constitutes an extensive scale of infrastructural and investment requirements; it opens up the perspectives for shaping unique spatial structures adjusted to the existing conditions. The natural context, historical and contemporary harbour and shipyard buildings and landscape values of the waterside areas - these all comprise the exclusive conditions that in the contemporary development and management of substantial harbour and shipyard areas influence the functional, urban and architectural solutions.
\end{abstract}

Key words: waterside architecture, natural and cultural environment.

\section{STRESZCZENIE}

Unikalne położenie na obszarach poprzemysłowych, sąsiadujących z centami współczesnych miast, graniczących z terenami krajobrazu naturalnego, posiadających dostęp do akwenów wodnych, stanowi rozległą skalę wymagań infrastrukturalnych i inwestycyjnych; otwiera perspektywy dla kształtowania wyjątkowych struktur przestrzennych, dostosowywanych do istniejących uwarunkowań. Kontekst przyrodniczy, historyczne i współczesne zabudowania portowo-stoczniowe, walory krajobrazowe terenów nadwodnych - stanowią unikalne uwarunkowania, których wykorzystanie przy współczesnej zabudowie i zagospodarowaniu rozległych terenów portowo-stoczniowych wpływa na rozwiązania funkcjonalne, urbanistyczno-architektoniczne.

Słowa kluczowe: architektura nadwodna, środowisko naturalne i kulturowe. 
The analysis of the preservation of the spatial structure of historical centres developing for centuries on the basis of the use of water reservoirs was carried out by the author during many years of research on the development of old cities and the concepts of their reconstruction after wartime destruction. It included complexes in Poland and Northern Europe countries as The Netherlands and Germany. The scope of work focused on a comparative analysis of influences and inspirations, as well as technological and material solutions reflecting unique location, civilisation and cultural conditions. The aim of the research was to define the principles of contemporary development and modern construction of historic areas that considered the era of their creation and at the same time referred to the centuries-old tradition of the place.

\section{INTRODUCTION}

The unique location of the industrial and harbour areas of Hamburg and Szczecin - are situated in the neighbourhood of old city districts, on the open areas of former production plants where the warehouses are located along riverbanks and harbour channels combined with an ecosystem of waterfront greenery. Those location determinants enable nowadays the shaping of spatial structures of unique architectural character distinguished by the integration of modern functional solutions with post-industrial building substance, exposed against the background of the natural landscape of water reservoirs.

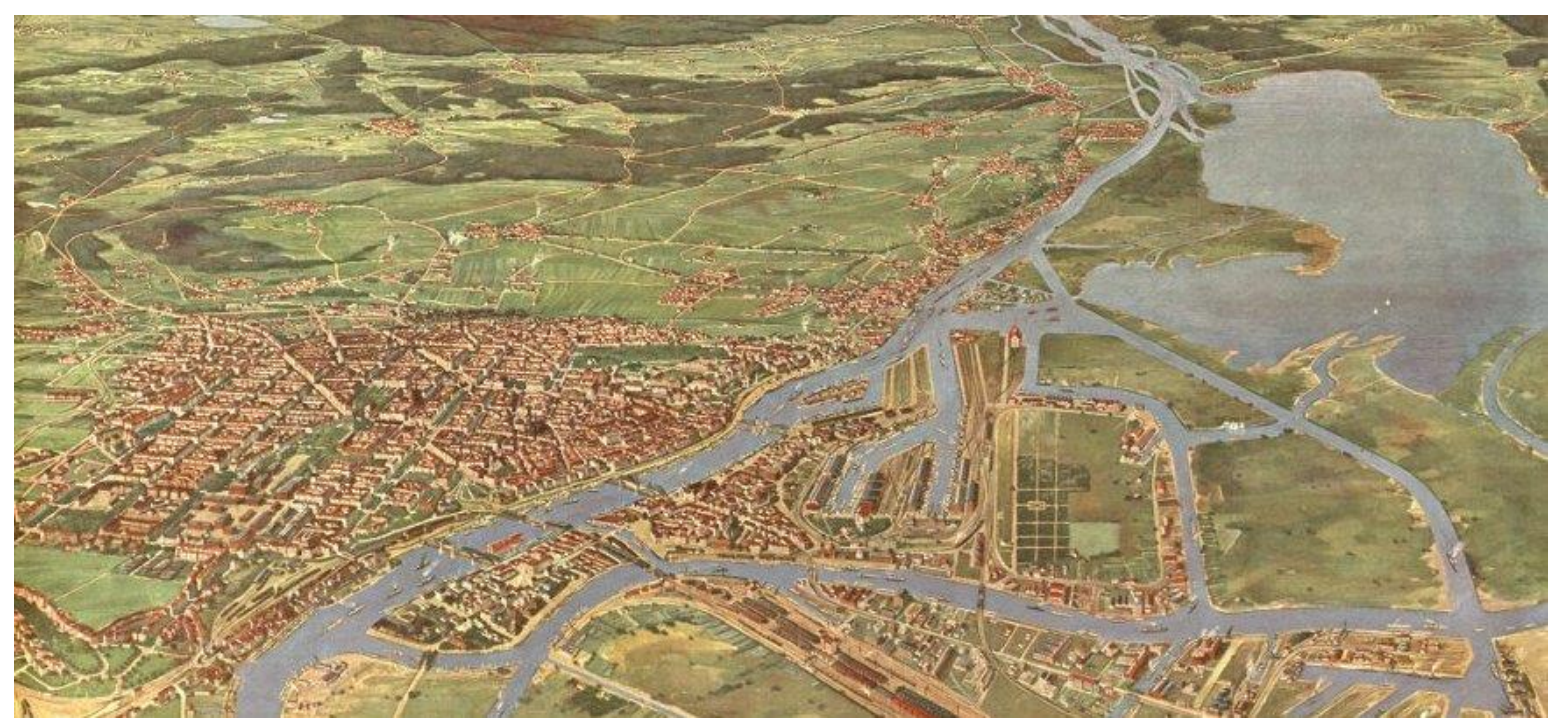

Fig. 1. Szczecin, waterfront city with harbour and shipyard complex, watercolour by J. Reupa 1928 (fragment). Source: Fotografie Szczecina 1921-1930

Rys. 1. Szczecin, nadwodne miasto z zespołem portu i stoczni, akwarela J. Reupa 1928 r. (fragment). Źródło: Fotografie Szczecina 1921-1930

\section{LOCATION DETERMINANTS}

A convenient location in terms of transport and nearness to the city centre, together with the potential size of planned construction projects on the absorptive area of former warehouses and production plants are among the most important conditions for modern investments in the area, which require complex organisational preparations and material expenditure. The harbour areas stand out in the structure of modern cities in terms of investment potential resulting from, among other things, an extensive transport and communication system: water, land, rail with target connections of express routes with airport terminals (comprehensive transport services were organised in industrial zones and waterfront areas strategic for public safety). The location along river embankments and 
port channels - at the main axes of entry to the centres - is particularly prominent in the structures of contemporary urban centres.

\section{HISTORICAL BACKGROUND OF SZCZECIN HARBOUR AND SHIPYARD COMPLEX}

Szczecin has been a strategically important centre of Northern Europe for centuries located at the crossroads of important trade routes and land and inland waterways. The political conditions in the difficult history of the city have influenced numerous changes in the nationality of Szczecin and Pomerania. The development of the city depended on the changing economic situation and it was subject to use its location potential near merchant routes of goods and raw materials transportation: between Northern Europe and Scandinavia as well as between East and West. Szczecin is one of the centres with a unique location in the system of water reservoirs: rivers, canals, lakes and the lagoon that combine to form an integrated system with the waters of the Baltic Sea. From the Middle Ages onwards, Szczecin's economy was based on the development of boatbuilding factories (later shipyards) and the expansion of the harbour complex. The periods of prosperity made it possible to designate new channels for the water transport of raw materials, agricultural and industrial goods as well as to strengthen new quays, which were equipped with modern reloading facilities - new investments and modernisations of the technical infrastructure ensured economic growth, reflected in the architecture of the harbour centres. Szczecin belonged to the most important reloading and shipbuilding centres of Northern Europe; the architectural landscape was identical with that of Bremen, Elblag, Danzig, Hamburg, Rotterdam, among others - the most important centres of the Hanseatic League, where the flow of goods was parallel to the transfer of information and new solutions. The greatest development of the industrial centre took place in the era of the industrial revolution. After the reunification of Germany in the 19th century, the harbours of Szczecin and Świnoujście provided the sea transport base for the industrial Berlin - the Oder and the new Havel canals ensured the connection with the German capital (at the turn of the 19th and 20th centuries, after the construction of the canal system in the northern part of the continent, the Oder ports lost their importance due to the potential to connect Berlin with the transhipment areas of Hamburg and Bremen, accessible via the North Sea with the deep sea and ocean routes).

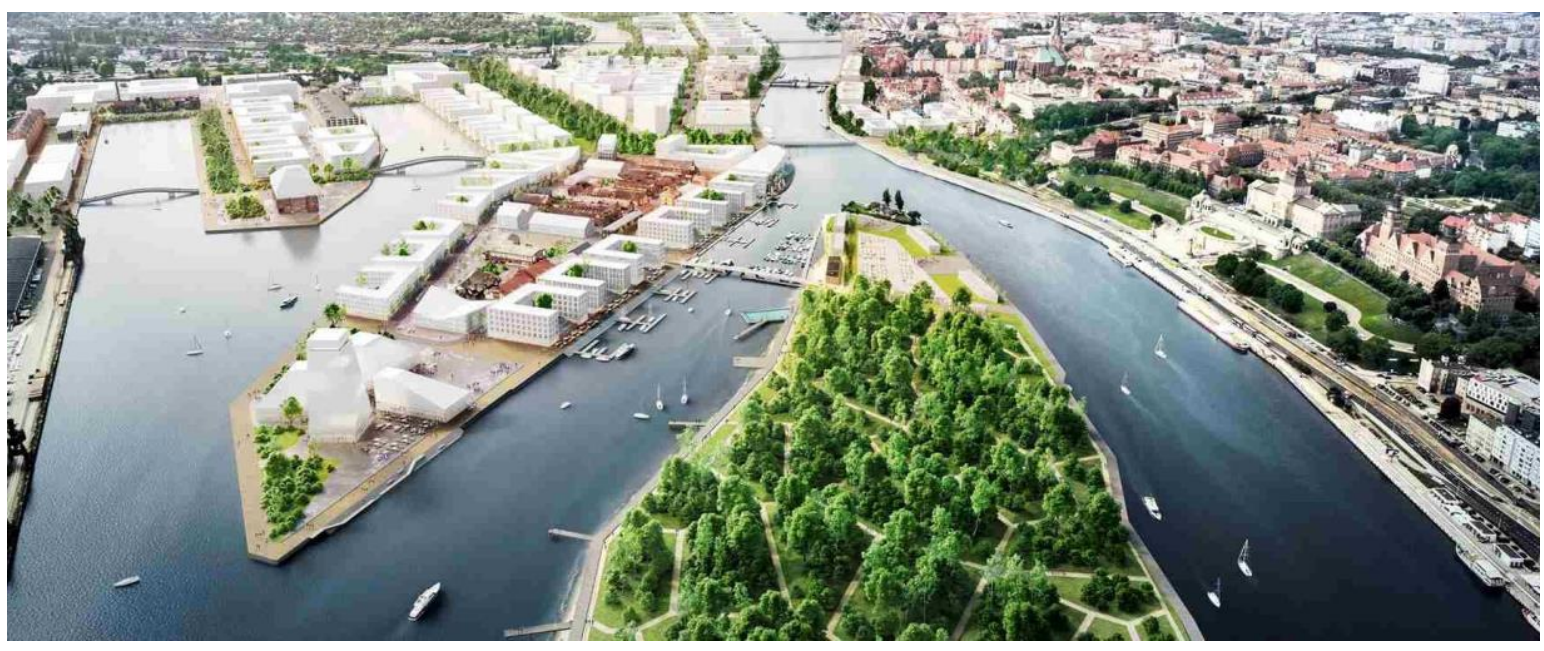

Fig. 2. Szczecin-Łasztownia, competition concept by Maćków Design Studio 2017 (fragment). Source: Konkurs 2017 Rys. 2. Szczecin-Łasztownia, koncepcja konkursowa Maćków Pracownia Projektowa 2017 (fragment). Żródło: Konkurs 2017

Development of industry was connected with development of urban layout in Szczecin (realised by J. Hobrecht, author of plans of enlarging the area of the capital city of Berlin in the second half of 
the 19th century, which referred to the solutions of Paris of that period). In the waterfront area, connected with the Old Town, the old buildings were transformed, creating a characteristic panorama of the port centre with silhouettes of tenement houses, granaries and warehouse buildings situated along the quay where ships and fishing boats used to arrive. The buildings of the old town were destroyed during the Allied bombing raids, the ruined houses (including the preserved tenement houses) were demolished in the waterfront area to make way for a wide traffic route; for decades the medieval district of the port centre was moved away from the shoreline. In the post-war years various planning concepts and urban solutions were developed for the area of the historical centre, located between zones of the agglomeration of several hundred thousand people, whose representative spaces were arranged at a considerable distance from the Oder River - the most important element in Szczecin's history, which was the basis of its economic prosperity. The reconstruction of the old town complex in the oldest part of the suburb, the former Slavic settlement in Podzamcze, belongs to the multifaceted plans for shaping the contemporary waterfront landscape of the city. In the post-industrial era and the period of digital revolution the former manufacturing functions were transformed or liquidated. The post-industrial areas have been included in revitalisation plans, preparing new investments in the area of the historical complexes of Łasztownia and Kępa Parnicka; the concepts refer to international Waterfront programmes ${ }^{1}$.

\section{CONDITIONS FOR THE DEVELOPMENT OF THE HAFEN CITY COMPLEX IN HAMBURG}

Hamburg is one of the most important industrial centres of Northern Europe, which has been developed since the Middle Ages on the mainland and the surrounding islands, around the natural floodplain of the Elbe and the harbour channels of the 19th and 20th centuries. The extensive harbour and shipyard centre was destroyed during the Second World War; also the valuable buildings of the Old Town have not been preserved to this day. The reconstruction of the harbour centre after 1945, important for the economy of the German state and its strategic goals, was prepared on the basis of multifaceted modernisation programmes which defined modern infrastructural, communication and spatial solutions. Factories and service plants were re-established on the basis of modern organisational and technological solutions (in comparison to the standards of industrial production at the beginning of the 20th century). For centuries, the city's buildings have been integrated into the landscape of the water bodies surrounding the Hamburg agglomeration; the natural environment has been transformed as the urban complex has grown dependent on the ability to use the rivers and lakes for goods transport, fishing and industrial production.

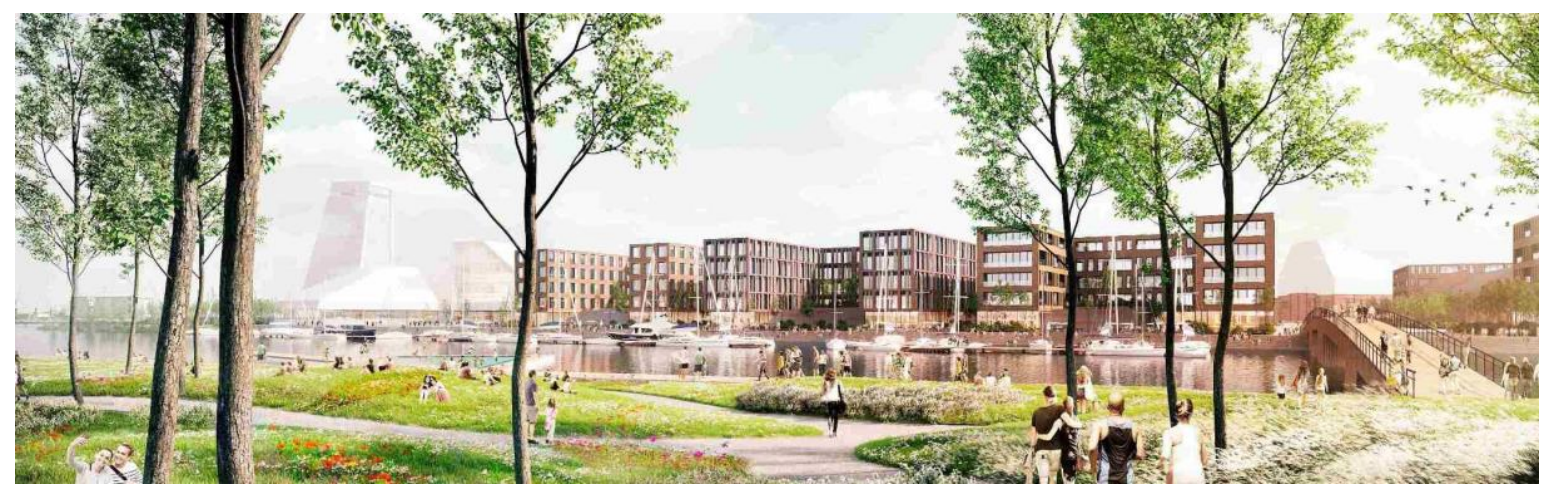

Fig. 3. Szczecin-Łasztownia, competition design by Maćków Design Studio 2017 (fragment). Source: Konkurs 2017 Ryc. 3. Szczecin-Łasztownia, projekt konkursowy Maćków Pracownia Projektowa 2017 (fragment). Źródło: Konkurs 2017

\footnotetext{
${ }^{1}$ The prospective strategy of the Szczecin Floating Garden is initiated, among other things, by the organization of cyclical, international Tall Ships Races, which are visited by numerous tourists from various countries (the record number exceeded one million people).
} 
The characteristic harbour architecture with brick facades of granaries and tenement houses constituted a substantial urban complex transformed in the following decades; wooden harbour buildings of warehouses, merchants' offices were replaced in the 19th and 20th centuries by modern constructions made of steel and ferroconcrete. The houses located in the waterfront area, devoid of sanitary facilities and water supply, were demolished in order to enlarge the storage area of the extended harbour complex.

The modern landmark of the city is the large-scale structure of the Hafen City district, which has been developed over the last two decades as a modern agglomeration centre. The architectural forms of the individual houses reflect the high status of the investors and the buildings erected with the participation of the local administration, are among the original solutions shaping the landscape of modern agglomerations. The individual forms of the buildings are emphasised by composed greenery complexes, planned with reference to carefully arranged quays of a modern harbour complex.

\section{CONTEMPORARY URBAN PLANNING CONCEPTS AND ARCHITECTURAL DESIGNS}

Investments in harbour areas and in the area of shipyard plants in many cases require advanced technologies for foundations on unstable geological substrate with high groundwater levels unfavourable for construction. Former industrial building constructions were built using wooden pile foundations and from the beginning of the 20th century - reinforced concrete ones; nowadays, significant financial expenses for preparing advanced pile foundations for the new buildings (requiring e.g. construction of underground storeys for technical equipment and garages) depend on the scope and size of investment programmes implemented. The permissible proportion of land development resulting from the development plans and the limiting height of the land determine the business decisions taken for complex and costly construction projects. Architectural concepts and urban planning analyses were prepared in the port cities to determine the business profitability potential in relation to the absorption capacity of the area; regardless of the unfavourable geological conditions the erection of tall buildings was envisaged (the outlays resulting from the costly foundation are limited by the size of the development area, ensuring - with several storeys - that the foundation costs of the tall house are balanced in comparison with the area of the building complex). The scale of costly investments is reflected in their functional structure and architectural solutions - as carefully arranged, non-standard layouts of flats, office complexes, hotels, retail services located in the water area belong to the distinctive architectural undertakings in the panorama of contemporary port cities. The distinctive appearance of the buildings reflects contemporary architectural trends and tendencies, which are an inspiration for similar investments in European centres ${ }^{2}$.

Conducting contemporary investments requires adjusting, in terms of composition, the new development to the historical context of the transformed industrial zones and to the natural landscape and natural conditions. Among the leading compositional ideas for the combination of new buildings with the old factory buildings are architectural solutions that use the artistic values of contrasting surfaces (glass, metal, synthetic, composite) with rough concrete walls and textured ceramic walls. The juxtaposition of reflective coatings and panels with old walls serves to emphasise the differences between modern constructions and systemic façade materials; the appearance of buildings created during the 19th century industrialisation and those constructed before the digital revolution. The architects use the contrasting juxtaposition of historical buildings with glass planes to achieve reflective effects, replicating the plastic effects of post-industrial buildings on contemporary fragments that were added to buildings situated in revitalised complexes of former factories.

\footnotetext{
${ }^{2}$ Famous projects, such as the philharmonic hall in Hamburg, museums in Bilbao and Stralsund, and the adaptation of docks in London, serve as models for investment plans, which are to provide comparable media effects.

In Szczecin the official strategy of the city authorities is to prepare advanced investments, which in the long term would make the capital of Western Pomerania as famous as the Mieczysław Karłowicz Philharmonic Hall in Szczecin, which has won prizes at international and national architectural competitions.
} 
One of the most interesting artistic solutions used in the development of post-factory buildings and historical residential and office buildings is the accentuation of mirror-like reflections of decorative façade elements on reflective surfaces. The historical detail - which stands out against the background of contemporary modular facades made of reflective coatings and panels - belongs to the sets of serially produced facade decorative elements in the 19th century, which were eclectic and neo-stylistic quotations of classical architectural styles. Historical forms of artistic decoration enrich the appearance of contemporary buildings. The new façades, formed with the use of the technologically advanced self-supporting systems and modern materials form a neutral background and provide a striking display for the historic plastic decoration. Original industrial equipment and furnishings are additional components that enrich the architectural landscape of the transformed former industrial complexes; irrespective of the possibility of their use in the planning of new functions. The traditional solutions include the use of materials similar to the existing finish on facades: the repetition of ceramic colours and concrete textures, which serve to consolidate the vast volumes of postindustrial complexes. It is also used to contrast the existing brick walls with reinforced concrete structures or the metal finish of the facades. The open spaces characteristic of former production complexes and the water context of harbour areas are among the sought-after formal and compositional qualities that influencing the individualised appearance of contemporary buildings, which are solved as structures that stand out from the existing surroundings. Spacious flats, office complexes, hotels, supplemented with commercial premises and generally available services are the most important parts of modern functional programmes realised in post-industrial areas. Shaping the space of contemporary apartment-office complexes and multifunctional retail-service complexes located in the areas of former production plants or in their vicinity, is carried out with the use of original technological devices and equipment of old buildings - platforms, trusses, cranes, overhead cranes, factory windows with fine divisions, skylights, cast-iron and steel details - which emphasize the industrial character of costly construction projects.

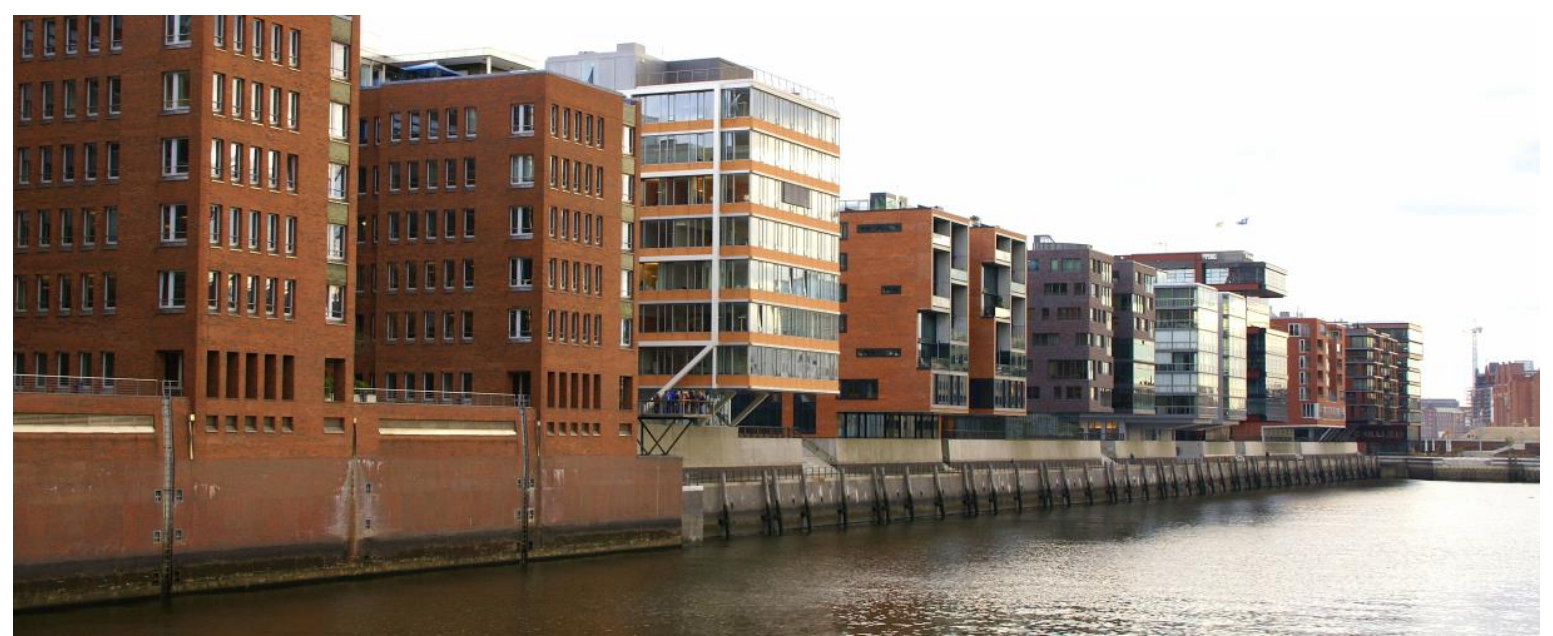

Fig. 4. Hamburg-HafenCity, a contemporary reminiscence of harbour architecture. Source: author's photo, 2006. Rys. 4. Hamburg-HafenCity, współczesna reminiscencja architektury portowej. Źródło: foto autora, $2006 \mathrm{r}$.

In order to emphasise the unique qualities of the location, new structural and formal solutions were designed with reference to the appearance of the old buildings and their equipment: a vertical communication and connection of successive levels (openwork stairs and platforms); spacious balconies and terraces on the roofs (cantilever structures and superstructures); illumination of deep passages of large residential and office spaces using large glazing with geometrically fragmented divisions (similar to the ways of providing natural light in factory halls). In large buildings, the inter- 
nal structure was solved with the use of overhead lighting, the introduction of mezzanine floors in high locations and communication platforms and galleries on upper levels. In valuable objects that belong to historic industrial complexes where they are distinguished by the preserved values of the old material and industrial culture, an important factor influencing the necessity to preserve the elements of the existing structure and coordinate the architectural solutions with the relevant administrative services - is their status: being entered in the register of monuments or in the records of monuments, being covered by the requirements of conservation, archaeological, landscape and exposure protection zones. Separate properties affecting the composition of contemporary developments, which are created within or in the vicinity of valuable objects, result from the fact that architects refer to the existing cultural context and a natural landscape, subordinating the solutions and a scope of investments to the unique spatial values.

Popular formal and plastic solutions of contemporary objects, adjacent to post-industrial buildings and post-factory interiors, reflect the characteristics of the Vintage trend (the trend of contemporary culture and art) - stylisation of solutions from previous decades, emphasising the "rusticity" of preserved surroundings from past epochs, exposing noble materials, details and equipment which represent the high level of old artistic craftsmanship. Furnishings with properties called (commonly referred to as) "retro" style serve to emphasise new materials and contemporary artistic forms contrasting or integrated with existing interiors (individualism is not defined solely by avant-garde search; original design concepts are also among the most outstanding traditional solutions). The structural potential of the former industrial buildings allows their multilateral adaptation to new functions: conversion of open spaces of production and storage interiors, superstructures and extensions using a stable load-bearing system adapted to carry considerable payloads. The adaptable layout of the changing use of warehouse and factory buildings provides enormous potential for the modern layout of new functions, designing mobile room layouts. The functional and structural features of the old industrial buildings are in contrast to the requirements set by modern conditions for technological development in the 21st century - the advanced digital age.The neighbourhood with natural complexes (habitat areas, ecosystem with rich fauna and flora occurring on undeveloped islands of Międzyodrze in Szczecin) provides incomparable - in comparison with other urban centres located in areas without water reservoirs - perspectives for modern urban solutions and architecture integrated with natural landscape. The location in the waterfront area enables unique coupling of modern housing, office and service buildings with water transport. The exposure of architecture in the vicinity of developed green systems, forming a unique waterfront natural ecosystem, is one of the distinctive locations in terms of landscape value; it provides a unique reference for contemporary building constructions, which are implemented with a careful functional-spatial development and an individual artistic development of the facade. The financial outlay associated with the acquisition of the property, the foundation and construction costs (requiring the use of advanced technologies), is reflected in the individual architectural form; aesthetic considerations are among the important factors in the shaping of buildings in exceptional areas, in the vicinity of rivers, lakes and water reservoirs used for tourist recreation and water sports. Multifaceted location, technological, transport and functional conditions influence the shaping of structural spatial solutions connected with greenery complexes, neighbouring at the same time with historical and contemporary post-industrial architecture.

\section{CONCLUSIONS AND PERSPECTIVES}

The exposition of an attractive contemporary architecture that is integrated with the system of river and harbour channels and the natural landscape of Szczecin's Międzyodrze along with the panorama of the vast Hafen City complex in Hamburg offers the unique perspectives for the development of important centres of Northern Europe. Further in the city on the Elbe River the next phases of a complex project are at an advanced stage. Szczecin's investment programmes were drawn up on the basis of multifaceted studies and conceptual analyses which, after several decades of preparation, were only marginally implemented.The harbour and shipyard complexes of Hafen City in Hamburg and Łasztownia in Szczecin are exceptional examples of initiating the development of modern and developing urban centres that take advantage of the unique location and landscape 
conditions. The unique conditions influence the character of the new development and at the same time define the potential for using non-standard spatial solutions and aesthetic values resulting from construction solutions, technology applied and finishing materials used. A contemporary architecture in post-industrial waterside complexes (Barcelona, Hamburg, London, Rotterdam, the Arsenal in Venice), is among the outstanding creations, the important achievement of the modern art of shaping space. The unique qualities include: the exposure of buildings against the background of the water mirror of rivers, integration with the natural environment and water reservoirs as well as the historical context of the post-industrial buildings and the panoramic relationship with the built-up areas of old-town and downtown districts.
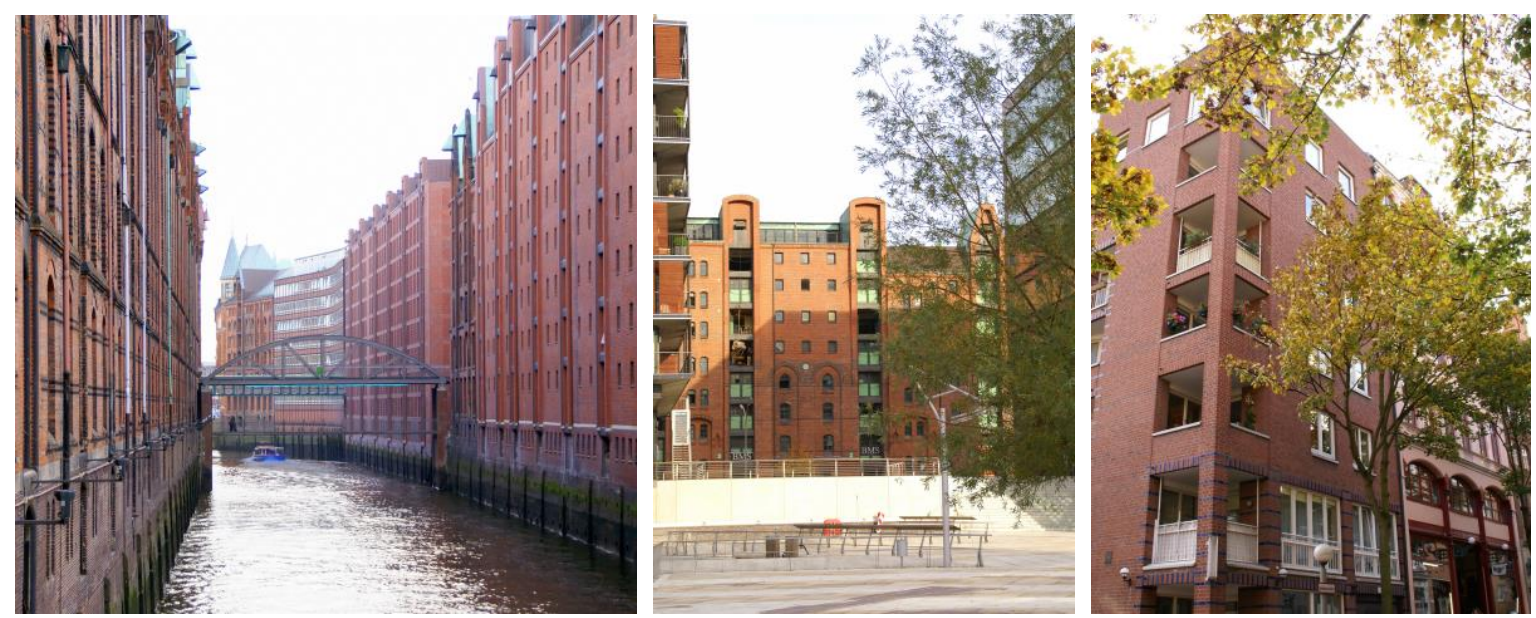

Fig. 5., 6., 7. Hamburg-HafenCity, granaries from 19th and 20th century, architecture integrated with greenery. Source: author's photo, 2006

Rys. 6., 7., 8. Hamburg-HafenCity, spichlerze z XIXIXX w., architektura zintegrowana z zielenią. Źródło: foto autora, 2006 r.

\section{INTEGRACJA WSPÓŁCZESNEJ ARCHITEKTURY ZE ŚRODOWISKIEM PRZYRODNICZYM I KULTUROWYM (AKWENY W ZESPOŁACH PORTOWYCH: HAFEN CITY W HAMBURGU I ŁASZTOWNIA W SZCZECINIE)}

Analiza zachowania struktury przestrzennej historycznych ośrodków, rozwijających się przez stulecia w oparciu o wykorzystanie akwenów wodnych, została prowadzona przez autora w trakcie wieloletnich badań nad rozwojem starych miast i koncepcjami ich odbudowy po zniszczeniach wojennych. Obejmowały zespoły w Polsce i Europie Północnej: Holandii i Niemczech. Zakres prac koncentrował się na analizie porównawczej wpływów i inspiracji oraz rozwiązań technologicznych i materiałowych, odzwierciedlających unikalne uwarunkowania lokalizacyjne, cywilizacyjne i kulturowe. Celem prac badawczych było dążenie do określenia zasad współczesnego zagospodarowania i nowoczesnej zabudowy zabytkowych obszarów, które odzwierciedlały epokę swojego powstania i jednocześnie nawiązywały do wielowiekowej tradycji miejsca. 


\section{WPROWADZENIE}

Wyjątkowa lokalizacja obszarów przemysłowo-portowych Hamburga i Szczecina - w sąsiedztwie dzielnic staromiejskich, na otwartych terenach dawnych zakładów produkcyjnych, składów magazynowych lokalizowanych wzdłuż nabrzeży rzek i kanałów portowych, połączonych z ekosystemem zieleni nadwodnej - umożliwia współcześnie kształtowanie struktur przestrzennych o wyjątkowym charakterze architektonicznym, wyróżniającym się zintegrowaniem nowoczesnych rozwiązań funkcjonalnych z postindustrialną substancją budowlaną, eksponowanych na tle krajobrazu naturalnego akwenów wodnych.

\section{UWARUNKOWANIA LOKALIZACYJNE}

Dogodne położenie pod względem komunikacyjnym oraz bliskość z centrum miasta, wraz z potencjałem wielkości planowanych przedsięwzięć budowlanych na chłonnym terenie dawnych składów i zakładów produkcyjnych, należą do najważniejszych uwarunkowań współczesnych inwestycji realizowanych na terenie, który wymaga skomplikowanych przygotowań organizacyjnych i nakładów materialnych. Tereny portowe wyróżniają się w strukturze współczesnych miast pod względem potencjału inwestycyjnego, wynikającego $m$.in. $z$ rozbudowanego systemu transportu i komunikacji: wodnej, lądowej, szynowej z docelowymi połączeniami tras ekspresowych z terminalami lotniczymi (wszechstronna obsługa komunikacyjna organizowana była w strefach przemysłowych i strategicznych dla bezpieczeństwa publicznego rejonach nadwodnych). Lokalizacja wzdłuż nabrzeży rzek i kanałów portowych - przy głównych osiach wjazdu do centrów - należy do szczególnie eksponowanych w strukturach współczesnych ośrodków miejskich.

\section{HISTORYCZNY KONTEKST SZCZECIŃSKIEGO ZESPOKU PORTU I STOCZNI}

Szczecin od stuleci stanowił ważny strategicznie ośrodek Europy Północnej, zlokalizowany na skrzyżowaniu ważnych szlaków handlowych oraz tras lądowych, śródlądowych połączonych $z$ akwenami morskim. Uwarunkowania polityczne w złożonej historii miasta wpłynęły na wielokrotne zmiany przynależności państwowej Szczecina i Pomorza. Rozwój miasta zależał od zmieniającej się koniunktury gospodarczej, zależny był od wykorzystania potencjału lokalizacyjnego przy szlakach kupieckich oraz dróg transportu towarów i surowców: między Europą Północną i Skandynawią oraz Wschodem i Zachodem. Szczecin należy do ośrodków o unikalnym położeniu w systemie akwenów wodnych: rzek, kanałów, jezior i zalewu, które łączą się w system zintegrowany z wodami Morza Bałtyckiego.

Gospodarka Szczecina od średniowiecza oparta była na rozwoju zakładów szkutniczych (późniejszych stoczni) i rozbudowywanym zespole portowym; okresy koniunktura umożliwiały wyznaczenie nowych kanałów dla wodnego transportu surowców, płodów rolnych i towarów przemysłowych oraz na umocnienie nowych nabrzeży, które wyposażano w nowoczesne urządzenia przeładunkowe nowe inwestycje i modernizacje infrastruktury technicznej zapewniały wzrost ekonomiczny, odzwierciedlony w architekturze portowych ośrodków.

Szczecin należał do najważniejszych ośrodków przeładunkowych i stoczniowych Europy Północnej; krajobraz architektoniczny tożsamy był z wyglądem m.in. Bremy, Elbląga, Gdańska, Hamburga, Rotterdamu - najważniejszych ośrodków Hanzy, w którym przepływ towarów przebiegał równolegle z przekazywaniem informacji i nowych rozwiązań. Największy rozwój przemysłowego ośrodka nastąpił w epoce rewolucji przemysłowej. Po zjednoczeniu Niemiec w XIX w. porty Szczecina i Świnoujścia stanowiły zaplecze transportu morskiego dla przemysłowego Berlina - Odra i nowe kanały Haweli zapewniały połączenie ze stolicą (na przełomie XIX/XX w., po wykonaniu systemu kanałów w północnej części kontynentu, porty nadodrzańskie straciły na znaczeniu ze względu na potencjał połączenia Berlina z terenami przeładunkowymi Hamburga i Bremy, dostępnych przez Morze Północne z trasami dalekomorskimi i oceanicznymi).

Rozwój przemysłu wiązał się z rozbudową w Szczecinie układu urbanistycznego (realizowanego przez J. Hobrechta, autora planów powiększenia obszaru stołecznego Berlina w II poł. XIX w., któ- 
re nawiązywały do rozwiązań Paryża z tego okresu). W strefie nadwodnej, połączonej ze Starym Miastem, nastąpiło przekształcenie starej zabudowy tworząc charakterystyczną panoramę portowego ośrodka, z sylwetami kamienic, spichlerzy, budynków magazynowych usytuowanych wzdłuż nabrzeża do którego dopływały okręty i łodzie rybackie. Zabudowa starego miasta uległa zniszczeniu podczas nalotów alianckich, zrujnowane domy (także zachowane kamienice) wyburzono w strefie nadwodnej dla rozplanowania szerokiej trasy komunikacyjnej; na dziesięciolecia średniowieczną dzielnicę portowego centrum odsunięto od linii brzegowej.

W latach powojennych opracowano różnorodne koncepcje planistyczne i rozwiązania urbanistyczne dla obszaru historycznego centrum, zlokalizowanego pomiędzy strefami kilkusettysięcznej aglomeracji, której reprezentacyjne przestrzenie urządzono w znacznym oddaleniu od Odry - najważniejszego elementu w historii Szczecina, który stanowił podstawę jego gospodarczej koniunktury. Odbudowa zespołu staromiejskiego w najstarszej części podgrodzia, dawnego osiedla słowiańskiego na Podzamczu, należy do wielostronnych planów kształtowania współczesnego krajobrazu nadwodnego miasta. W epoce postindustrialnej i okresie cyfrowej rewolucji dawne funkcje produkcyjne uległy przekształceniu lub likwidacji. Tereny poprzemysłowe objęto planami rewitalizacji, przygotowując nowe inwestycje na obszarze historycznych zespołów Łasztowni i Kępy Parnickiej; koncepcje nawiązują do międzynarodowych programów Waterfront ${ }^{3}$.

\section{UWARUNKOWANIA ROZWOJU KOMPLEKSU HAFEN CITY W HAMBURGU}

Hamburg należy do najważniejszych ośrodków przemysłowych Europy Północnej, który od średniowiecza rozwijany był na stałym lądzie i okolicznych wyspach, wokół naturalnego rozlewiska Łaby i kanałów portowych z XIX i XX w. Rozległy ośrodek portowo-stoczniowy uległ zniszczeniu podczas II wojny światowej, również cenna zabudowa Starego Miasta w znacznej części nie zachowana została do naszych czasów.

Odbudowa portowego ośrodka po 1945 r., ważnego dla gospodarki państwa niemieckiego i jego strategicznych celów, przygotowana została na podstawie wielostronnych programów modernizacyjnych, które określały nowoczesne rozwiązania infrastrukturalne, komunikacyjne, przestrzenne. Przywrócono działalność fabryk i zakładów usługowych w oparciu o nowoczesne rozwiązania organizacyjne i technologiczne ( $w$ porównaniu ze standardami produkcji przemysłowej $z$ początku XX w.). Zabudowa miasta od stuleci była zintegrowana z krajobrazem akwenów wodnych, otaczających aglomerację Hamburga; środowisko przyrodnicze ulegało przekształceniu wraz z powiększaniem się zespołu miejskiego, uzależnionego od możliwości wykorzystania rzek i jezior dla transportu towarów, rybołówstwa i produkcji przemysłowej.

Charakterystyczna architektura portowa z ceglanymi fasadami spichlerzy i kamienic stanowiła rozległy zespół urbanistyczny, przekształcany przez kolejne dziesięciolecia; drewniane zabudowania portowe magazynów, kantorów kupieckich, zastępowano w XIX/XX w. nowoczesnymi konstrukcjami ze stali i żelazobetonu. Zlokalizowane w strefie nadwodnej domy mieszkalne, pozbawione urządzeń sanitarnych i wodociągowych, wyburzono dla powiększenia powierzchni magazynowej rozbudowywanego kompleksu portu.

Współczesną wizytówką miasta jest rozległa struktura dzielnicy Hafen City, realizowana od ponad dwóch dekad jako nowoczesne centrum aglomeracji, składające się z obiektów o zróżnicowanym programie funkcjonalnym, których budowę dostosowano do wymagających uwarunkowań nadwodnej lokalizacji. Formy architektoniczne indywidualnych domów odzwierciedlają wysoki status inwestorów, budynki wznoszone przy udziale lokalnej administracji należą do oryginalnych rozwiązań, kształtujących krajobraz współczesnych aglomeracji. Indywidualne formy budynków podkreślają komponowane zespoły zieleni, rozplanowane $z$ nawiązaniem do starannie urządzonych nabrzeży współczesnego zespołu portowego.

\footnotetext{
${ }^{3}$ Perspektywiczna strategia Szczecina Floating Garden inicjowana jest m.in. organizacją cyklicznych, międzynarodowych Zlotów Żaglowców (Tall Ships Races), które odwiedzają liczni turyści z różnych państw (rekordowa liczba przekroczyła milion osób).
} 


\section{WSPÓŁCZESNE KONCEPCJE URBANISTYCZNE I PROJEKTY ARCHITEKTONICZNE}

Inwestycje na terenach portowych i w rejonie zakładów stoczniowych wymagają w wielu przypadkach zastosowania zaawansowanych technologii dla posadowienia na niestabilnym podłożu geologicznym, z niekorzystnym dla budowy wysokim poziomem wód gruntowych. Dawne konstrukcje zabudowań przemysłowych realizowano z wykorzystaniem drewnianych konstrukcji palowych, od początku XX w. żelbetowych; współcześnie ponoszone znaczne nakłady finansowe dla przygotowania zaawansowanych palowych fundamentów dl nowych budynków (wymagających m.in. budowy podziemnych kondygnacji dla urządzeń technicznych i garaży) uzależnione są od zakresu i wielkości realizowanych programów inwestycyjnych. Wynikająca z planów zagospodarowania dopuszczalna proporcja zabudowy terenu oraz graniczna jej wysokość, determinują podejmowane decyzje biznesowe złożonych i kosztownych przedsięwzięć budowlanych.

Koncepcje architektoniczne i analizy urbanistyczne przygotowywano w miastach portowych dla określenia potencjału opłacalności biznesowej w odniesieniu do chłonności terenu; niezależnie od niekorzystnych uwarunkowań geologicznych przewidywano wzniesienie budynków wysokich (nakłady wynikające z kosztownego posadowienia równoważy ogranicza wielkość terenu zabudowy, zapewniająca - przy kilkunastu kondygnacjach - bilansowanie się kosztów fundamentowania domu wysokiego, w porównaniu z powierzchnią kompleksu budynków).

Skalę kosztownych inwestycji odzwierciedla ich struktura funkcjonalna i rozwiązania architektoniczne - starannie zaaranżowane, niestandardowe układy apartamentów, zespołów biurowych, hoteli, usług handlowych zlokalizowanych w strefie akwenów wodnych należą do wyróżniają się przedsięwzięć architektonicznych w panoramie współczesnych miast portowych. Wyróżniający się wygląd zabudowy odzwierciedla współczesne tendencje i nurty architektoniczne, które stanowią inspirację dla analogicznych inwestycji w ośrodkach europejskich ${ }^{4}$.

Prowadzenie współczesnych inwestycji wymaga dostosowania, pod względem kompozycyjnym, nowej zabudowy do kontekstu historycznego przekształcanych stref industrialnych oraz do naturalnych uwarunkowań krajobrazowych i przyrodniczych. Do wiodących idei kompozycyjnych, zestawienia nowych obiektów z dawnymi zabudowaniami fabrycznymi, należą rozwiązania architektoniczne wykorzystujące walory plastyczne kontrastu płaszczyzn (szklanych, metalowych, syntetycznych, kompozytowych) z szorstkimi ścianami wykonanymi z betonu i fakturowymi murami ceramicznymi. Zestawienie refleksyjnych powłok i paneli ze starymi murami, służy podkreśleniu odmienności nowoczesnych konstrukcji i systemowych materiałów fasadowych; wyglądu budynków powstałych w okresie XIX-wiecznej industrializacji i wzniesionych przed okresem rewolucji cyfrowej. Architekci wykorzystują kontrastowe zestawiane historycznych zabudowań, z płaszczyznami szklanymi, dla uzyskania efektów refleksyjnych, powielając efekty plastyczne zabudowy postindustrialnej na współczesnych fragmentach, które dobudowano do obiektów usytuowanych w rewitalizowanych zespołach dawnych zakładów produkcyjnych.

Do najbardziej interesujących rozwiązań plastycznych, stosowanych przy rozbudowie obiektów pofabrycznych oraz historycznych zabudowań mieszkalnych i biurowych, należy uwypuklanie na płaszczyznach posiadających właściwości refleksyjne, lustrzanych odbić dekoracyjnych elementów elewacyjnych. Detal historyczny - wyróżniający się na tle współczesnych modularnych fasad z powłok refleksyjnych i paneli - należy do zestawów seryjnie produkowanych w XIX w. elementów wystroju elewacyjnego, które stanowiły eklektyczne i neostylowe cytaty klasycznych stylów architektonicznych. Formy historyczne artystycznego wystroju wzbogacają wygląd współczesnych budynków. Nowe elewacje, kształtowane z zastosowaniem zawansowanych technologicznie systemów samonośnych i nowoczesnych materiałów tworzą, jako neutralne tło, efektowaną ekspozycję dla zabytkowej dekoracji plastycznej. Oryginalne urządzenia przemysłowe i elementy wyposażenia należą do dodatkowych składników, które wzbogacają krajobraz architektoniczny przekształcanych

\footnotetext{
4 Słynne realizacje: filharmonia w Hamburgu, muzea w Bilbao i Stralsundzie, adaptacje doków w Londynie służą jako wzór dla planów inwestycyjnych, które miałyby zapewnić porównywalne z wymienionymi efekty medialne.

W Szczecinie oficjalną strategią władz miasta jest przygotowywanie zaawansowanych inwestycji, które w perspektywie miałyby rozsławić stolicę Pomorza Zachodniego w zakresie porównywalnym z nagradzaną na międzynarodowych i krajowych konkursach architektonicznych Filharmonią im. Mieczysława Karłowicza w Szczecinie.
} 
dawnych zespołów przemysłowych; niezależnie od możliwości ich wykorzystania przy planowaniu nowych funkcji.

Do rozwiązań tradycyjnych należy zastosowanie na elewacjach materiałów podobnych do istniejącego wykończenia: powtórzenia kolorystyki ceramicznej i faktury betonu, które służą scaleniu obszernych kubatur zespołów poprzemysłowych. Stosowane jest także kontrastowanie istniejących ścian ceglanych z żelbetowymi konstrukcjami lub metalowym wykończeniem fasad.

Charakterystyczne dla przestrzeni dawnych zespołów produkcyjnych otwarte przestrzenie oraz kontekst wodny terenów portowych, należą do poszukiwanych walorów formalnych i kompozycyjnych, wpływających na zindywidualizowanie wyglądu współczesnych obiektów, które rozwiązywano jako struktury wyróżniające się z istniejącego otoczenia. Przestronne apartamenty, kompleksy biurowe, hotele, uzupełnione o lokale handlowe i ogólnodostępne usługi stanowią najważniejsze części współczesnych programów funkcjonalnych, realizowanych na terenach postindustrialnych. Kształtowanie przestrzeni współczesnych zespołów apartamentowo-biurowych i wielofunkcyjnych kompleksów handlowo-usługowych, lokalizowanych na obszarach dawnych zakładów produkcyjnych lub w ich sąsiedztwie, realizowane jest przy wykorzystaniu oryginalnych urządzeń technologicznych i wyposażenia starych obiektów - pomostów, kratownic, dźwigów, suwnic, okien fabrycznych z drobnymi podziałami, świetlików, żeliwnego i stalowego detalu - które podkreślają charakter industrialny kosztownych przedsięwzięć budowlanych.

Dla podkreślenia niepowtarzalnych walorów lokalizacyjnych, nowe rozwiązania konstrukcyjne i formalne projektowano z nawiązaniem do wyglądu dawnych zabudowań i ich wyposażenia: komunikacja pionowa i łączenie kolejnych poziomów (ażurowe schody i pomosty); przestronne balkony i tarasy na dachach (wspornikowe konstrukcje i nadbudowy); doświetlenie głębokich traktów dużych powierzchni mieszkalnych i biurowych z zastosowaniem wielkich przeszkleń z geometrycznym rozdrobnieniem podziałów (podobnie do sposobów zapewnienia światła naturalnego $w$ halach fabrycznych). W obszernych obiektach wewnętrzną strukturę rozwiązywano z zastosowaniem oświetlenia górnego, wprowadzaniem w wysokich lokalach antresoli, na wyższych poziomach pomostów i galerii komunikacyjnych.

W cennych obiektach, które należą do historycznych zespołów przemysłowych i wyróżniają się pod względem zachowanych wartości dawnej kultury materialnej i przemysłowej, istotnym czynnikiem wpływającym na konieczność zachowania elementów istniejącej struktury oraz koordynowania z właściwymi służbami administracyjnymi, rozwiązań architektonicznych, jest ich status: wpisania do rejestru zabytków lub ewidencji zabytków, objęcia wymaganiami stref ochrony konserwatorskiej, archeologicznej, krajobrazu i ekspozycji. Odrębne właściwości wpływające na kompozycję współczesnych realizacji, powstających w obrębie lub sąsiedztwie wartościowych obiektów, wynikają z nawiązania przez architektów do zastanego kontekstu kulturowego i naturalnego krajobrazu, podporządkowując rozwiązania i zakres inwestycji do unikalnych wartości przestrzennych.

Popularne rozwiązania formalno-plastyczne współczesnych obiektów, sąsiadujących z zabudowa postindustrialną oraz wnętrz pofabrycznych, odzwierciedlają cechy nurtu Vintage (nurtu współczesnej kultury i sztuki) - stylizacji na rozwiązania z poprzednich dekad, podkreślenia „rustykalności” zachowanego otoczenia z minionych epok, ekspozycji szlachetnych materiałów, detalu i wyposażenia, które reprezentują wysoki poziom dawnego rzemiosła artystycznego. Elementy wyposażenia posiadające właściwości nazywane (w potocznym odbiorze) stylem „retro”, służą podkreśleniu nowych materiałów i współczesnych form plastycznych - kontrastujących lub zintegrowanych z istniejącymi wnętrzami (indywidualizm nie jest określony wyłącznie przez poszukiwania awangardowe; oryginalne koncepcje projektowe należą również do najwybitniejszych tradycyjnych rozwiązań).

Potencjał konstrukcyjny dawnych obiektów przemysłowych umożliwia ich wielostronną adaptację do nowych funkcji: przekształcenie otwartych przestrzeni wnętrz produkcyjnych i magazynowych, nadbudowę i rozbudowę wykorzystując stabilny układ nośny dostosowany do przenoszenia znacznych obciążeń użytkowych. Uniwersalny układ zmieniającego się użytkowania hal magazynowych i budynków fabrycznych stanowi ogromny potencjał dla współczesnego rozplanowania nowych funkcji, projektowania mobilnego układu pomieszczeń. Cechy funkcjonalne i konstrukcyjne starych 
zabudowań przemysłowych stanowią przeciwieństwo wymagań, jakie określają współczesne warunki dla rozwoju technologicznego w XXI w. - zaawansowanej epoki cyfrowej.

Sąsiedztwo z zespołami przyrodniczymi (terenami siedliskowymi, ekosystemem z bogatą fauną i florą występującą na niezabudowanych wyspach Międzyodrza w Szczecinie) określa nieporównywalne $-\mathrm{z}$ innymi ośrodkami miejskimi, zlokalizowanymi na terenach pozbawionych akwenów wodnych - perspektywy dla nowoczesnych rozwiązań urbanistycznych i architektury zintegrowanej z krajobrazem naturalnym. Położenie w rejonie nadwodnym umożliwia unikalne sprzężenie współczesnej zabudowy mieszkaniowej, biurowej i usługowej z transportem wodnym.

Eksponowanie architektury w sąsiedztwie rozwiniętych systemów zieleni, tworzących unikalny nadwodny ekosystem przyrodniczy, należy do wyróżniających lokalizacji pod względem walorów krajobrazowych; zapewnia wyjątkowe odniesienie dla współczesnych konstrukcji budowlanych, które realizowane są ze starannym opracowaniem funkcjonalno-przestrzennym i indywidualnym opracowaniem plastycznym elewacji. Nakłady finansowe związane z nabyciem nieruchomości, kosztami posadowienia oraz budowy (wymagającej zastosowania zaawansowanych technologii), odzwierciedla indywidualna forma architektoniczna; względy estetyczne należą do istotnych czynników kształtowanej zabudowy na wyjątkowych terenach, w sąsiedztwie rozlewisk rzek, jezior i akwenów służących rekreacji turystycznej i sportów wodnych. Wielostronne uwarunkowania lokalizacyjne, technologiczne, transportowe, funkcjonalne wpływają na kształtowanie strukturalnych rozwiązań przestrzennych, powiązanych z zespołami zieleni, sąsiadujących jednocześnie z historyczną i współczesną architekturą postindustrialną.

\section{WNIOSKI I PERSPEKTYWY}

Ekspozycja atrakcyjnej współczesnej architektury, zintegrowanej z systemem akwenów rzek i kanałów portowych, w krajobrazie naturalnym szczecińskiego Międzyodrza i panoramie rozległego kompleksu Hafen City w Hamburgu, stanowi unikalne perspektywy dla rozwoju ważnych ośrodków Europy Północnej; w mieście nad Łabą - w zaawansowanym etapie realizacji kolejnych faz złożonego przedsięwzięcia. Szczecińskie programy inwestycyjne opracowano na podstawie wielostronnych prac studialnych, koncepcyjnych analiz, które po kilku dekadach przygotowań zrealizowano w niewielkim stopniu.

Zespoły portowo-stoczniowe Hafen City w Hamburgu i Łasztownia w Szczecinie stanowią wyjątkowe przykłady zainicjowania rozbudowy współczesnych, rozwijających się ośrodków miejskich, wykorzystując unikalne uwarunkowania lokalizacyjne i krajobrazowe. Wyjątkowe uwarunkowania wpływają na charakter nowej zabudowy, określają jednocześnie potencjał dla wykorzystania niestandardowych rozwiązań przestrzennych i walorów estetycznych, wynikających z rozwiązań konstrukcyjnych, zastosowanej technologii i użytych materiałów wykończeniowych. Współczesna architektura w nadwodnych kompleksach poprzemysłowych (Barcelony, Hamburga, Londynu, Rotterdamu, Arsenału w Wenecji) należy do wyróżniających się kreacji, zaliczanych do ważnych osiągnięć nowoczesnej sztuki kształtowania przestrzeni; do unikalnych walorów należy ekspozycja budynków na tle lustra wodnego rzek, zintegrowanie ze środowiskiem przyrodniczym i akwenami wodnymi, a także kontekst historyczny budowli i urządzeń poprzemysłowych oraz panoramiczne relacje z zabudową dzielnic staromiejskich i śródmiejskich.

\section{BIBLIOGRAPHY}

Białecki T., red. Hasła: Łasztownia; - Stettiner Maschinebau-Acien-Gesellschaft Vulcan; - Stocznia Pomerania Sp. z o.o.; - Stocznia Porta Odra Sp. z. o.o.; - Stocznia Remontowa Parnica Sp. z. o.o.; - Stocznia Szczecińska; Tor wodny Szczecin-Świnoujście, [w:] Encyklopedia Szczecina, Szczecińskie Towarzystwo Kultury, Szczecin 2015, s. 541-544, 978-979, 983-989, 1102-1104.

Fiuk P., Szczecin - Płynny potencjał, [w:] „Architektura\&Biznes” nr 3/2009, Kraków 2009.

Fiuk P.: Architektura starych miast w relacji z krajobrazem naturalnych akwenów wodnych (Wenecja, Hamburg, Rotterdam, Gdańsk, Szczecin), [w:] Architektura w krajobrazie. Harmonia - Kompromis - Konflikt, 
red. W. Kobylińska-Bunsch, Instytut Historii Sztuki Uniwersytetu Warszawskiego, Warszawa 2018, s. 223-242.

Fiuk P.: Łasztownia i Kępa Parnicka w Szczecinie - idea rewitalizacji historycznych zespołów przemysłowoportowych, [w:] Rewitalizacja - nośnik tożsamości i rozwoju obszarów metropolitalnych, red. B. Walczak, Międzynarodowa Konferencja PRO-REVITA, Wydawnictwo Biblioteka i Instytut Architektury i Urbanistyki Politechniki Łódzkiej, Łódź 2007, s. 483-488.

Fiuk P.: Łasztownia und Kępa Parnicka in Szczecin. Revitalisierung des postindustriellen Hafen- und Werftkomplexes in der postindustriellen Ära; 25. Konferencja Grupy Roboczej Polskich i Niemieckich Historyków Sztuki i Konserwatorów Zabytków Miasto postindustrialne i jego dziedzictwo w XXI wieku. OchronaKonserwacja-Rewitalizacja, Centralne Muzeum Włókiennictwa w Łodzi, 11-14 października 2017 (przyjęty do druku w wersji niemieckojęzycznej).

Fotografie Szczecina 1921-1930 http://bip.um.szczecin.pl/chapter_50741.asp?soid=B96F7F8BF1C949E1BEA 1306DD5FE517E, dostęp 12.02.2019

Gołębiewski J.I., Plany rewitalizacji Wyspy Grodzkiej w Szczecinie, [w:] Czasopismo Techniczne. Technical Transactions, 1-A/2012, Zeszyt 1, Rok 109, Politechnika Krakowska, Kraków 2012, https://suw.biblos.pk.edu.pl, dostęp/access 11.01.2018

Gołębiewski J.I., Transformacja obszarów i obiektów postindustrialnych w szczecinie pod funkcje biurowe. Projekty, realizacje, perspektywy rozwoju, [w:] Nowoczesność w architekturze, Konferencja Naukowa „Urbanistyka i architektura miasta postindustrialnego”, RAr2 2011, Gliwice 2012

Konkurs 'Łasztownia. nowe serce miasta'. Żródło: http://www.mackow.pl/news/konkurs-lasztownia-noweserce-miasta/, Dostęp: 12.02.2019

Lange, R. Hamburg. Wiederaufbau und Neuplanung 1943-1963, Hamburg, Langewiesche (Die Blauen Bücher) 1994

Marka Floating Garden http://www.szczecin.eu/marka/aktualnosci/szczecin_przyszlosci_floating_garden, (Floating Garden-Pływający Ogród, Dokument programowy Długoterminowej Strategii Urzędu Miasta w Szczecinie). dostęp/access 2020.12.05

Paszkowski Z., Planowanie transformacji szczecińskich wysp Międzyodrza, [w:] „Przestrzeń i Forma” nr 12, Szczecin 2009, s. 355-374.

Schildhauer J., Dzieje i kultura Hanzy, Państwowy Instytut Wydawniczy, Warszawa 1995, s. 13-51, 105-140.

Strategia Rozwoju Szczecina 2025", Urząd Miasta w Szczecinie, [w:] http://bip.um.szczecin.pl /chapter_11124.asp?soid=8ED6AD35235F4C07B05B8D5F81CF4090. dostęp/access 10.02.2018

\section{AUTHOR'S NOTE}

dr hab. inż. arch. Piotr FIUK, Prof. ZUT (1964). Graduate of the Szczecin University of Technology (1990), doctoral thesis: Municipal tenement house at the turn of the 19th and 20th centuries (...) of Szczecin (...), Cracow University of Technology (2000), habilitation: Architecture of the rebuilt city (...), professor at ZUT (2020) in the Department of History and Conservation of Monuments, Faculty of Architecture. Specialisation: history of modern and contemporary architecture, conservation of monuments and revalorisation of old towns (author of studies on protection of cultural assets, projects of reconstruction and rebuilding of old town houses in Szczecin and Kostrzyn nad Odrą). Author of artistic works (drawing, graphics, painting) and art photography.

\section{O AUTORZE}

dr hab. inż. arch. Piotr FIUK, prof. ZUT (1964). Absolwent Politechniki Szczecińskiej (1990), doktorat: Miejska kamienica czynszowa z przełomu XIXIXX w. (...) Szczecina (...), Politechnika Krakowska (2000), habilitacja: Architektura miasta odbudowanego (...), profesor ZUT (2020) w Katedrze Historii i Konserwacji Zabytków Wydziału Architektury. Specjalizacja: historia architektury nowożytnej i współczesnej, konserwacja zabytków i rewaloryzacja starych miast (autor studiów ochrony dóbr kultury, projektów rekonstrukcji i odbudowy kamienic staromiejskich w Szczecinie i Kostrzynie nad Odrą). Autor prac plastycznych (rysunek, grafika, malarstwo) i fotografii artystycznej.

Contact | Kontakt: Piotr.Fiuk@zut.edu.pl 